\title{
Are Hugs, Carrots and Sticks Essential for Energy Policy: A Study of Latvia's National Energy and Climate Plan
}

\author{
Reinis ABOLTINS ${ }^{1 *}$, Dzintars JAUNZEMS ${ }^{2}$, Jelena PUBULE ${ }^{3}$, Dagnija BLUMBERGA ${ }^{4}$ \\ ${ }^{1-4}$ Institute of Energy Systems and Environment, Riga Technical University, \\ Azenes iela 12/1, Riga, LV-1048, Latvia
}

\begin{abstract}
The purpose of the study was to analyse Latvia's NECP2030 impact on energy user by identifying the activities/policy measures by their type and their impact on the choices and actions of energy users. The goal of the Latvian National Climate and Energy Plan for 2030 (NECP2030) is to achieve changes in the use of energy with a possibly better impact on climate and environment. Energy user, its choices and action play an essential role in achieving this goal. Latvia's NECP2030 has 12 activity groups each encompassing one or more activity clusters with several specific activities and policy measures that are intended to influence the use of energy resources and energy. The method of hugs, carrots and sticks was used to categorise activities and through applying literature analysis on policy goals and most appropriate policies identify whether the chosen activities are adequate to achieve NECP2030 goals. The study concludes that in case of four activity groups the identified activities might not be sufficient as literature suggests that more stringent measures are recommended to effectively achieve certain policy goals.
\end{abstract}

Keywords - Energy and climate plan; energy policy; hugs, carrots and sticks; policy instruments

\section{INTRODUCTION}

Development towards a climate-neutral energy policy in the EU is set out in The European Green Deal (EGD) communication, which is the most recent EU framework document aimed at ensuring that the EU adheres to climate neutral sector policies and principles of circular economy. It envisages that net neutrality of GHG emissions will be achieved by 2050 , economic growth will be untied from an increasing consumption of [all types of] natural resources. Long-term climate neutrality has been endorsed as a major goal for the EU by the European Parliament and the European Council. The European Green Deal has eight policy pillars [1]. To ensure that the Member States adhere to the long-term goals of the EGD the European Commission (EC) has prepared a proposal for EU Climate Regulation [2] as it believes that a legislative act of direct applicability is most appropriate for the purpose.

The goal of this analysis is to determine if the policy instruments chosen to ensure that NECP2030 goals are reached are adequate and sufficient. Analysis is based on literature about impact of various policies on energy users and environment. Latvia's NECP2030 has been reviewed through this filter to identify whether the activities - identified as hugs, carrots and

* Corresponding author.

E-mail address: Reinis.Aboltins@rtu.lv 
sticks - and that have been identified in the Strategic Environmental Impact Assessment (SEIA) as having impact on environment correspond the experience and correlations identified in literature.

\section{Methodology}

\subsection{Approach of the study}

There are 13 groups of policy measures (activity directions) in NECP2030 where one group encompasses so called horizontal activities and 12 groups represent sector-specific policy measures, which, in turn, encompass activities grouped in clusters according to their specific purpose. As the study aims to determine whether policy measures (activities) represented in NECP2030 are adequate and sufficient to reach the desired goals, analysis was done in four steps illustrated in Fig. 1 representing the algorithm of the study.

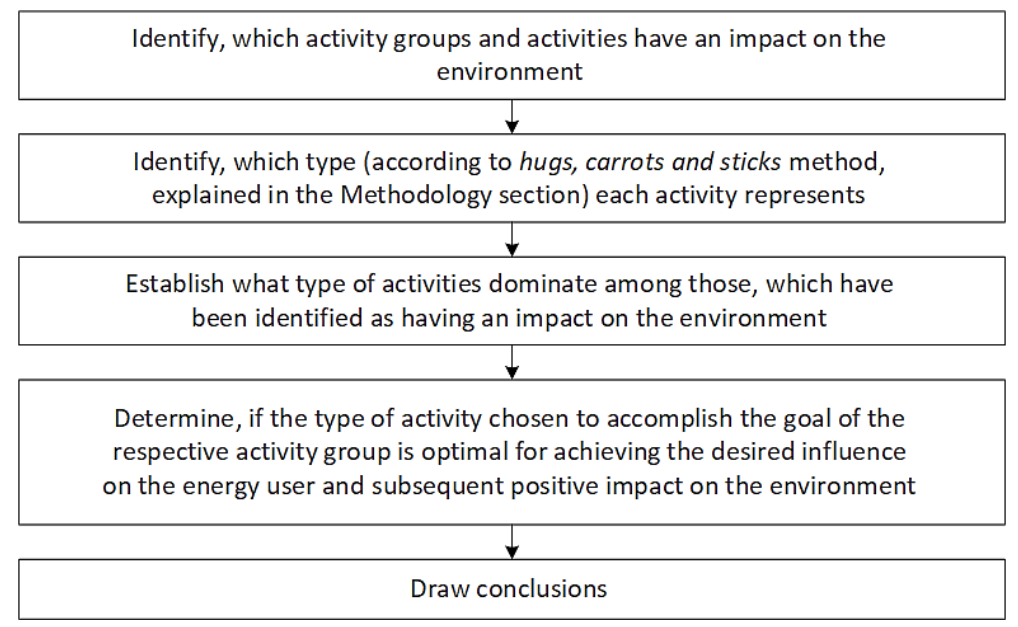

Fig. 1. Algorithm of analysis used in the study.

\subsection{Hugs, carrots and sticks}

Finding the right balance between different types of policies is at times a challenging task for policymakers. This study builds analysis on the hugs, carrots and sticks approach to identify, which type of policy measure each of the NECP2030 activities (policy instruments) represents creating basis for further in-depth analysis of adequacy and / or balance of measures included in the NECP2030. "Hugs, carrots and sticks" (HCS) approach has been used to identify, which policy instrument and action belongs to which group. The purpose of hugs is to achieve a consensus through convincing, educating and participation. Carrots reward and compensate for the desired action. Sticks allow achieving the desired effect (action) through applying compulsory methods, threats or punishment [3]. The HCS approach associated with the work of Kenneth Boulding, a Nobel Prizes nominee in economics, has gained popularity and has been used widely to analyse, formulate and apply different policy instruments with the aim of achieving the desired economic behaviour, using education, reward or imposition to mobilise individuals for action [4] and employing learning as an essential tool for achieving behavioural change [5]. Further, it is argued that a correct balance 
of persuasion [6], coercion [7], possibility to avoid loss [8] and benevolent motivating measures [9] is essential to stimulate rational behaviour [10].

In the case of NECP2030 a carrot is any kind of positive stimulus and gain for energy user if energy is produced and used in an environmentally friendly way. A stick is a measure characterised by enforcement, creation of an obligation and inconvenience costs for energy user with the intent that from the point of view of energy production and consumption it pays to be environmentally friendly. A hug encompasses measures and activities like research, information, education, exchange of experience, visiting of pilot projects, advertising best practice, involvement in the discussion about social responsibility, assuring energy user about positive effects of acting in an environmentally conscious way as well as other activities facilitating change of social opinion.

Following are examples of each type of action / policy instrument:

A hug: information or education campaign, showing best practice, visits to demonstration projects, research or analysis to provide information for decision-making.

A carrot: favourable regulatory environment, financial instrument and co-financing for the purchase and installation of renewable energy technology (for example, PV panels or solar thermal collector). Electricity net metering system is an example (Latvia's Electricity Market Law, Article 30).

A stick: cancellation of tax rebates for fossil fuels, higher real estate tax for those properties, where the owner chooses not to implement energy efficiency measures although it is technically possible to do it and financial support is available for this purpose.

When analysing the impact of activity directions and activities (policy measures) listed in Appendix 4 of NECP2030 on environment and energy user by applying the HCS approach, the "H, C and S" have been replaced by A, B and C respectively for the purpose of data collection and easier perception. The same approach is used in the visualisation (Fig. 4) of the results of analysis. Activities/policy measures can be identified also as combined, for example, AB, AC, BC or ABC. The logic of identification of type of activity/policy measure is illustrated in Fig. 2. All policy instruments (activities) belonging to activity groups and activity clusters have been assessed according to the "hugs, carrots and sticks" approach. 


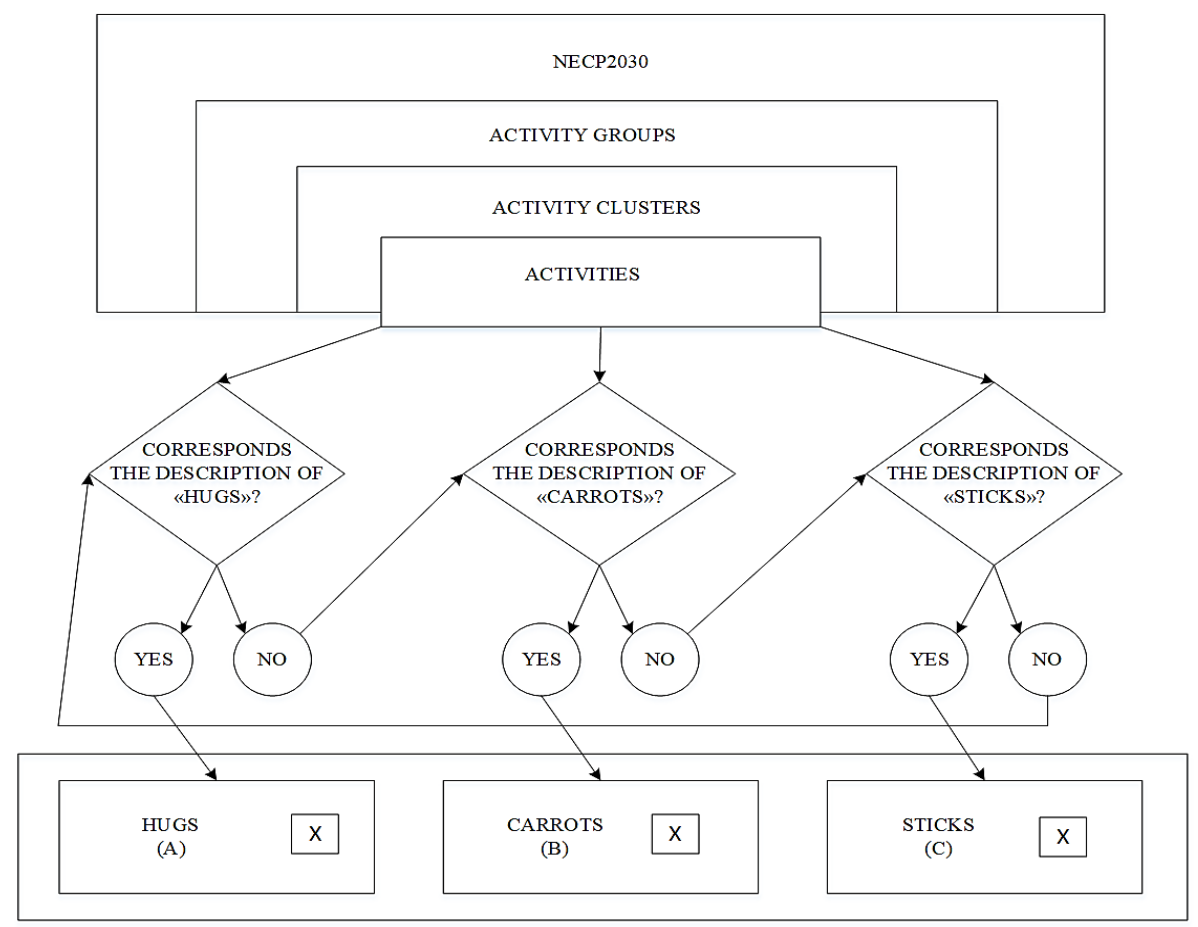

Fig. 2. Identification of the type of activity (authors' own visualisation).

\subsection{Impact on energy user}

Influence must be exercised on energy user to achieve changes in energy user's behaviour. Impact on energy user can be characterised as a separate activity or set of activities, which, if implemented, makes energy user to change his/her model of energy consumption (for example, by consuming less energy (becoming more energy efficient), not choosing fossil energy and instead choosing renewable energy).

When analysing change of attitude and behaviour, Gardner and Stern refer to William Ophuls concluding that coordinating behaviour of individuals for the sake of common good (for example, environment) has always been a problem, and that there are few simple methods how to stimulate individual's socially responsible behaviour [11]. Ophuls identifies four types of solutions to facilitate individual's socially responsible behaviour: 1) use of laws, regulations and stimuli; 2) education programmes, which try to achieve socially responsible behaviour by providing information and trying to change people's attitude; 3) facilitate socially responsible behaviour through non-governmental processes, which works well within smaller social groups and communities; and 4) use of moral, religious and ethical arguments to achieve socially responsible behaviour [12].

Similar approach has been used to analyse the impact of NECP2030 on energy user and environment, concluding that impact on energy user is stimulated through education, information, research, innovation, sanctions, compulsory mechanisms, inconvenience costs. Gardner and Stern's approach is represented in Fig. 3. 


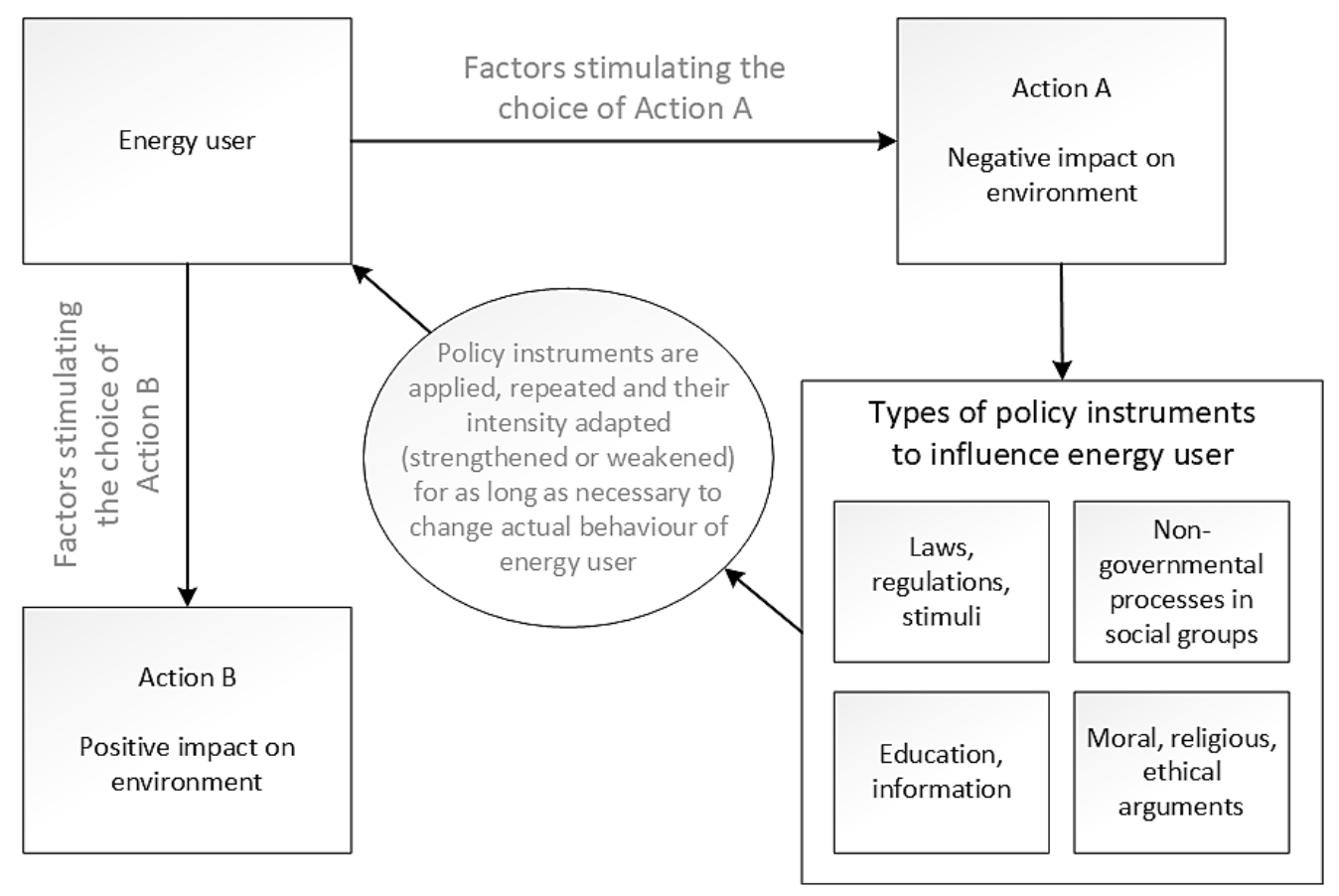

Fig. 3. Schematic representation of the impact on energy user.

There can be many reasons why people cannot act in a way that would represent their values and attitude. Let us say somebody is willing to cut expenses for energy, but this person simply does not know how much he/she will be able to save by insulating house, installing a more efficient boiler or other electrical appliances. This person may not have financial resources, or he/she might lack willingness to replace a fully functional heating system for the sake of achieving more noble goals. It can well turn out that lack of action is predetermined by lack of trust in builders, or perchance the particular person does not have the right to make decision about changes in the infrastructure of the apartment or house [13]. In other words, the more barriers of this type there are, the less influence on actual behaviour even a strong conviction that energy must be saved is going to have.

Gardner and Stern refer also to another research, about households, which indicates that positive attitude towards energy saving will result in action (behavioural change), which does not require big investment and is easy to implement, for example - turning the temperature of the thermostat of heating devices a few degrees lower. However, the higher the costs of the expected action, the lower the correlation between attitude and action. In this context Rosenow's analysis must be mentioned, which shows that in the UK energy efficiency measures that are based on behavioural change would be able to provide additional 6 percent of energy savings in households by 2035 compared to 2015 [14]. This demonstrates the potential that behavioural change has in improving energy efficiency in households.

Research about attitude and behaviour vis-à-vis environment show that even if a correct attitude facilitates action directed at solving environmental problems, attitude functions only as a marker that action might follow and even then - under certain conditions. Probability 
that action will follow attitude is in situations where a strong barrier to action is taken down, which is often related to availability of finances.

\subsection{Impact on environment}

Impact of NECP2030 activities on environment has been assessed in a separate study. According to Latvia's legislation a compulsory Strategic Environmental Impact Assessment (SEIA) is compulsory for every strategic policy planning document and NECP2030 is subject to this requirement as well. Authors of the SEIA for NECP2030 have assessed whether each of the Activity clusters (e.g., Activity cluster 1.1. or 1.2., etc.) has or does not have impact on environment and whether the impact is negative providing further detail whether impact is direct or indirect, short-term or long-term, primary or secondary, reversible or irreversible [15].

It should be noted that the conclusions of the SEIA do not affect identification of activities / policy instruments as belonging to one or more of the three categories/types (A, B or C). References to the assessment of NECP2030 activities in the SEIA are used to see how the activities relate to the impact on environment and whether there is any correlation between the type of activity and its impact on environment or lack of impact.

\section{RESUlts}

Impact of the NECP2030 on energy user was forecasted and identified through assessing the potential influence of policy measures on energy user. After assessing and identifying activities/policy measures according to the hugs, carrots and sticks (or A, B and C) methodology (described in Section 2.1) the following conclusions can be made. NECP2030 has 101 activity cluster encompassing 255 activities/policy measures in total. Of the total number 141 activity can be identified as hugs or type (A) activities, 120 activities as carrot or category (B) activities and 60 as stick or type (C) activities. One and the same activity can be identified as belonging to one separate category $(\mathrm{A}, \mathrm{B}$ or $\mathrm{C})$ or two categories (A and $\mathrm{B}$, $\mathrm{A}$ and $\mathrm{C}, \mathrm{B}$ and $\mathrm{C})$ or even all three categories $(\mathrm{A}, \mathrm{B}$ and $\mathrm{C})$ at the same time, therefore the total number of activities by type (A, B or C) can appear higher than the total number of activities.

Activities by type vary within activity groups and among activity clusters, however, type (A) (hugs) dominates. The number of type (C) (sticks) and (B) (carrots) activities is equal and their number is higher than that of type (A) activities only in the activity group RV 8. The proportion of activities identified as hugs, carrots and sticks varies among NECP2030 activity groups as is illustrated in Fig. 4. 
NECP2030 Activity groups by type

(A - "hugs", B - "carrots", C - "sticks")

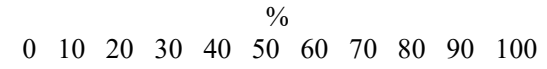

RV 1. Improving energy efficiency in buildings

RV 2. Improving energy efficiency and facilitating use of RES technologies in heating and cooling, and industry

RV 3. Facilitating use of non-emission technologies in electricity production

RV 4. RV 4. Facilitating economically justified energy production, consumption and renewable energy communities

RV 5. Improving energy efficiency, and use of alternative fuels and renewable energy technologies in transport

RV 6. Energy security, reducing energy dependency, full integration of energy markets and modernising of infrastructure

RV 7. Improving efficiency of waste and wastewater management and reducing GHG emissions

RV 8. Effective use of resources and reducing of GHG emissions in agriculture

RV 9. Sustainable use of resources and reducing GHG emissions and increasing $\mathrm{CO} 2$ sequestration in land-use, land use change and forestry sector

RV 10. Facilitating decrease in use of fluorinated GHG gases (F-gases)

RV 11. "Greening" of the tax system and improving its attractiveness for energy efficiency and RES technologies

RV 12. Informing and educating society, and raising awareness

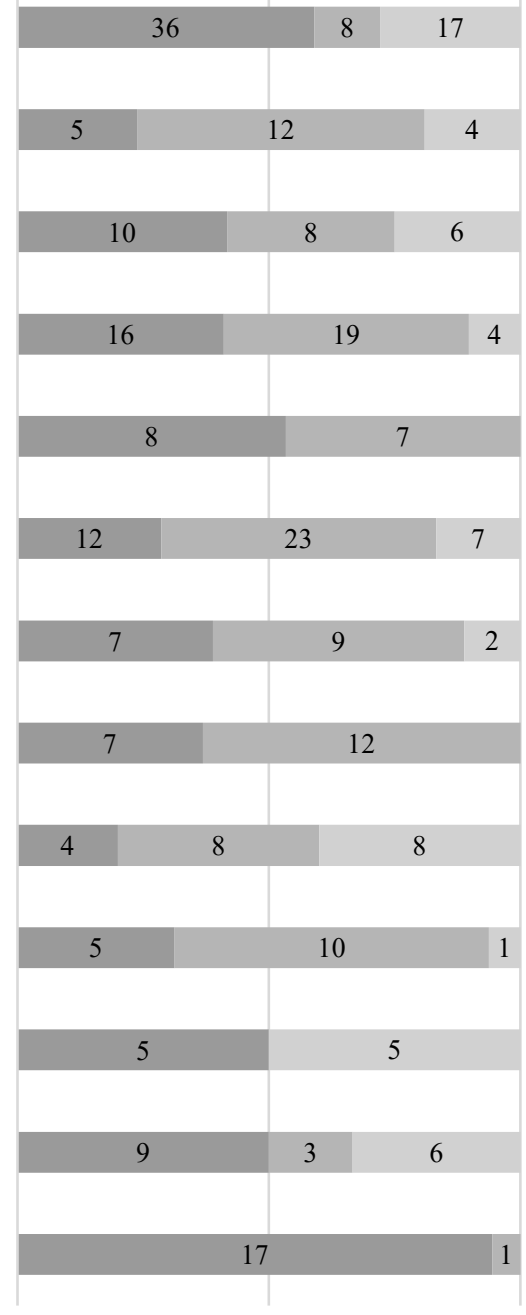

$$
\square \mathrm{A} \quad \mathrm{B} \quad \mathrm{C}
$$

Fig. 4. Proportion of activities in NECP2030 Activity groups by type.

A more detailed overview of results of those NECP2030 activity groups is presented, where the dominant type of activity would likely be insufficient to achieve the desired result. Activity groups RV 3, 4, 5 and 7 are reviewed for this purpose in more depth identifying aspects that might turn out to be problematic on the course of achieving the goals of each of the aforementioned activity groups. 


\subsection{RV 3. Facilitating use of non-emission technologies in electricity production}

Activity group "Facilitating use of non-emission technologies in electricity production" has 7 activity clusters encompassing 32 activities. 16 of those activities are identified as type (A), 19 as type (B) and 4 as type (C) activities. According to SEIA two groups (1 and 3) out of seven have negative impact on environment, but five (2, 4 to 7 ) have no impact on environment. Of activities that according to SEIA do not have impact on environment 14 are type (A), 9 are type (B) and 4 are type (C) activities (see Table 1 for illustration).

TABle 1. ACTIVITy Clusters of ACTIVITy GROUP 3 (RV 3)

\begin{tabular}{|c|c|c|c|c|c|c|c|}
\hline & \multicolumn{5}{|c|}{ Activities (by type) } & \multicolumn{2}{|c|}{$\begin{array}{l}\text { Impact on } \\
\text { environment } \\
\text { according to SEIA }\end{array}$} \\
\hline Activity groups & $\begin{array}{l}\text { Number } \\
\text { of } \\
\text { Activity } \\
\text { groups }\end{array}$ & $\begin{array}{l}\text { Total } \\
\text { number } \\
\text { of } \\
\text { activities }\end{array}$ & $\begin{array}{l}\text { A } \\
\text { (hugs) }\end{array}$ & $\begin{array}{l}\text { B } \\
\text { (carrots) }\end{array}$ & $\begin{array}{l}\mathrm{C} \\
\text { (sticks) }\end{array}$ & $\begin{array}{l}\text { Impact of } \\
\text { Activity } \\
\text { cluster } \\
\text { Positive / } \\
\text { Negative }\end{array}$ & $\begin{array}{l}\text { Activity } \\
\text { cluster } \\
\text { has No } \\
\text { impact }\end{array}$ \\
\hline $\begin{array}{l}\text { RV 3. Facilitating use of non- } \\
\text { emission technologies in } \\
\text { electricity production }\end{array}$ & 7 & 31 & 16 & 19 & 4 & 1,3 & $2,4-7$ \\
\hline $\begin{array}{l}\text { RV } 3.1 \text { Implementing cross- } \\
\text { border offshore wind farm } \\
\text { projects (in cooperation with } \\
\text { Lithuania / Estonia) }\end{array}$ & & 5 & 1 & 4 & 0 & Negative & \\
\hline $\begin{array}{l}\text { RV } 3.2 \text { Reviewing existing } \\
\text { conditions for limitations to } \\
\text { deployment of RES technologies } \\
\text { associated with territory, } \\
\text { construction rules and use of } \\
\text { land }\end{array}$ & & 7 & 3 & 4 & 4 & & No \\
\hline $\begin{array}{l}\text { RV 3.3 Elaborating conceptual } \\
\text { solution for the development of } \\
\text { wind farms on land (wind } \\
\text { energy production) }\end{array}$ & & 6 & 1 & 6 & 0 & Negative & \\
\hline $\begin{array}{l}\text { RV } 3.4 \text { Facilitating use of solar } \\
\text { energy in electricity production }\end{array}$ & & 1 & 1 & 1 & 0 & & No \\
\hline $\begin{array}{l}\text { RV } 3.5 \text { Implementing the } \\
\text { assessment needed for further } \\
\text { development of RES electricity }\end{array}$ & & 5 & 5 & 0 & 0 & & No \\
\hline $\begin{array}{l}\text { RV 3.6 Facilitating trading of } \\
\text { RES electricity }\end{array}$ & & 4 & 4 & 1 & 0 & & No \\
\hline $\begin{array}{l}\text { RV } 3.7 \text { Supporting development } \\
\text { of innovative and energy } \\
\text { efficient solutions to increase } \\
\text { RES share in the energy system } \\
\text { (electricity supply, heating, } \\
\text { cooling) }\end{array}$ & & 3 & 1 & 3 & 0 & & No \\
\hline
\end{tabular}

Activity groups 1 (RV 3.1) and 3 (RV 3.3) have negative impact on environment. These two activity clusters, which are related to the development of wind energy, according to SEIA, are the only two activity clusters with negative impact on environment in all of the NECP2030. The goal of activity cluster 3.6 is to facilitate RES energy trading and activities 
to achieve this goal are type (A) and type (B) activities while numerous sources suggest that mandatory trading of RES electricity would help to achieve the goal more effectively [16]. Choosing a particular policy instrument or a set of instruments can facilitate development of renewable energy technologies for electricity production and contribute to $\mathrm{CO}_{2}$ mitigation [17]. For example, RES electricity quota system can be an effective way to promote production of RES electricity [18] while creating a burden on other (non-RES) power producers, just as renewable energy certificate system can be an effective way to promote RES albeit with potential negative social costs [19]. Similarly, renewable energy portfolio standards [20], feed-in tariffs and targeted tendering schemes can boost deployment of renewable energy technologies [21], but can deliver differing results depending on the design of particular renewable energy policy instrument [22]. Voluntary RES support mechanisms based on supply-side offers to consumers in the form of various electricity products appear to be inefficient [23] requiring to have some sort of a more targeted approach depending on energy technology preferences [24] for achieving a rapid and dynamic deployment of particular technologies [25] and availability of renewable electricity for all consumers. Less mature renewable energy technologies require stable support over longer period of time while those that have achieved certain market penetration can rely on less persistent and usually market-based support mechanisms such as green certificates or tradable permits [26]. Green certificates are considered to be a better choice from the perspective of authorities as they are more cost-effective than fixed price and more stable support schemes such as feed-in tariffs [27]. Possibility to trade certificates is considered an important precondition for investment in RES electricity production [28] while the more complex the combinations of so called black (emissions), green (renewable electricity) and white (energy savings) certificate schemes, the higher the risk that the effects of simultaneous implementation of different certificate systems can undermine the effectiveness of green certificates in particular [29].

\subsection{RV 4. Facilitating economically justified own energy production, consumption and renewable energy communities}

Activity group "Facilitating economically justified energy production, consumption and renewable energy communities" has 6 activity clusters encompassing 15 activities. 8 of those activities are identified as type (A) and 7 as type (B). No type (C) activities have been identified. According to SEIA two groups (1 and 4) out of six have positive impact on environment, but other have no impact on environment. As Table 2 illustrates, of activities that according to SEIA have positive impact on environment 5 are type (A), but no activities have been identified as type (B) and type (C) activities. Activity cluster RV 4.3 has both type (A) and type (B) activities. Of activities that according to SEIA have no impact on environment type (A) (RV 4.2, 4.3, 4.5, 4.6) and type (B) (RV 4.3) activities have been identified. 
TABle 2. ACTIVITy Clusters of ACTIVITy GROUP 4 (RV 4)

\begin{tabular}{|c|c|c|c|c|c|c|c|}
\hline \multicolumn{6}{|c|}{ Activities (by type) } & \multicolumn{2}{|c|}{$\begin{array}{l}\text { Impact on environment } \\
\text { according to SEIA }\end{array}$} \\
\hline Activity groups & $\begin{array}{l}\text { Number of } \\
\text { Activity } \\
\text { groups }\end{array}$ & $\begin{array}{l}\text { Total } \\
\text { number of } \\
\text { activities }\end{array}$ & $\begin{array}{l}\text { A } \\
(h u g s)\end{array}$ & $\begin{array}{l}\mathrm{B} \\
\text { (carrots) }\end{array}$ & $\begin{array}{l}\mathrm{C} \\
\text { (sticks) }\end{array}$ & $\begin{array}{l}\text { Impact of } \\
\text { Activity cluster } \\
\text { Positive / } \\
\text { Negative }\end{array}$ & $\begin{array}{l}\text { Activity } \\
\text { cluster has } \\
\text { No impact }\end{array}$ \\
\hline $\begin{array}{l}\text { RV 4. Facilitating } \\
\text { economically justified } \\
\text { own energy production, } \\
\text { consumption and } \\
\text { renewable energy } \\
\text { communities }\end{array}$ & 6 & 15 & 8 & 7 & 0 & 1,4 & $2,3,5,6$ \\
\hline $\begin{array}{l}\text { RV 4.1 Elaborating legal } \\
\text { framework for own } \\
\text { energy production and } \\
\text { consumption }\end{array}$ & & 4 & 0 & 4 & 0 & Positive & \\
\hline $\begin{array}{l}\text { RV } 4.2 \text { Elaborating } \\
\text { solutions to facilitate use } \\
\text { of net electricity } \\
\text { metering }\end{array}$ & & 4 & 4 & 0 & 0 & & No \\
\hline $\begin{array}{l}\text { RV } 4.3 \text { Facilitating } \\
\text { development of energy } \\
\text { communities and } \\
\text { renewable energy } \\
\text { communities }\end{array}$ & & 3 & 1 & 2 & 0 & & No \\
\hline $\begin{array}{l}\text { RV } 4.4 \text { Facilitating use } \\
\text { of RES technologies in } \\
\text { farms }\end{array}$ & & 1 & 0 & 1 & 0 & Positive & \\
\hline $\begin{array}{l}\text { RV } 4.5 \text { Facilitating use } \\
\text { of RES technologies in } \\
\text { public sector }\end{array}$ & & 2 & 2 & 0 & 0 & & No \\
\hline $\begin{array}{l}\text { RV } 4.6 \text { Facilitating more } \\
\text { effective tariff } \\
\text { methodology for } \\
\text { electricity transmission } \\
\text { and distribution }\end{array}$ & & 1 & 1 & 0 & 0 & & No \\
\hline
\end{tabular}

In activity cluster 4.5, which has the goal of facilitating use of RES technologies in public sector, two activities can be identified as type (A). Although attempts to make almost-standalone renewable energy systems for buildings cost efficient and competitive, it still appears that grid connections are necessary and incentives are required to facilitate deployment of RES technologies as sources of energy in buildings [30] especially if complex solutions with energy storage systems [31] and renovation of historic buildings is involved [32]. Persisting policy and regulatory uncertainty acts as a barrier to the roll-out of RES systems for individual buildings [33] despite particularly good potential of technologies such as, for example, solar thermal heating [34]. Energy user behaviour [35] and physical limitations of available space for RES energy installation [36] also play an important role in motivating RES integration as different patterns of use of energy can either hamper or foster use of RES energy. At the same technological development in sectors such as transport amplify the motivation to integrate 
renewables into energy systems of buildings - possibility to charge electric vehicles using, for example, solar PV energy, can strongly support the cause of integration of RES [37]. Limited space and concentration of economic activity in densely populated cities with high density of commercial and public buildings is another factor driving research and investment in RES integration in buildings [38]. Although support policies and incentivisation of integration of RES technologies in buildings dominate as key factors, existing research also suggests that it would be reasonable to introduce obligations and mandatory actions vis-à-vis public sector actors along with incentives. For example, a requirement to assess possibility to integrate RES technologies in case of renovation of a building, thus making the course towards the goal more efficient and purposeful [39].

\subsection{RV 5. Improving energy efficiency, and use of alternative fuels and renewable energy technologies in transport}

Activity group "Improving energy efficiency and use of alternative fuels and renewable energy technologies in transport" has 14 activity clusters encompassing 34 activities. 12 of those activities are identified as type (A), 13 as type (B) and 7 as type (C) activities. According to SEIA 9 groups $(1,2,3,4,5,8,12,13,14)$ out of 14 have positive impact on environment, but others have no impact on environment. Of activities that according to SEIA have positive impact on environment 7 are type (A), 17 are type (B) and 6 are type (C) activities. Of activities with no impact on environment 4 are type (A), 6 are type (B) and 1 is type (C) activity.

Activities of cluster 5.8 are aimed at "facilitating use of railway as a backbone of a modern and environmentally friendly public transportation". According to SEIA this activity cluster has positive impact on environment. From the point of view impact on energy user activities of the cluster are type (A) and type (B) activities. Analysis of factors facilitating change of behaviour of energy users suggests that to achieve the desired goal (facilitate use of public transport) type (C) (sticks) activities might be needed at least until energy users have adapted their behaviour to the new conditions - they are using public transport instead of private transport, thus contributing to a better and more efficient use of energy [40]. While type (B) activities like providing information [41], combining information with adapted or new services [42] is an important factor that narrows the gap between willingness to shift to public transportation actual behaviour [43], choosing public transportation is a conscious decision affiliated with goal-directed behaviour [44] that can be affected by interventions that produce change in attitudes [42] as well as additionally motivating factors such as increasing traffic congestions [45].

\section{4. $R V$ 7. Improving efficiency of waste and wastewater management and reducing GHG emissions}

Activity group "Improving efficiency of waste and wastewater management and reducing GHG emissions" has 4 activity clusters encompassing 12 activities. 7 of those activities are identified as type (A), 12 as type (B) and none as type (C). According to SEIA two groups (1 and 3) have positive impact on environment and two have no impact on environment. Of activities that according to SEIA have positive impact on environment none are type (A) or (C), 5 are type (B) activities. Of activities with no impact on environment one is type (A) and one is type (B) activity while there are no type (C) activities.

According to SEIA activities in two activity clusters have positive impact on environment although no type (C) activity has been identified to achieve the goals of the cluster. For 
example, activity cluster 7.1 (Reducing the volume of dumped waste, facilitating sorting, recycling and regeneration of different kinds of waste) has several only type (B) activities that, according to NECP2030, will allow to successfully reach the goal. However, literature analysis indicates that type (B) activities aimed at generating particular socially approved or disapproved behaviour or internal moral motivation might not be efficient enough to achieve the desired result [46] and type (C) activities might be required to implement a successful change of behaviour in waste management and circulation. Following measures have been identified as effective in achieving better waste collection, sorting and recycling results: weight-based waste tariff [47], [48], assigning specific monetary charges to desirable and undesirable environmental effects [49], reducing the number of waste collection times per month to increase pressure on households to recycle [50], introducing unit-based tariffs for waste along with accessibility of sorting and recycling infrastructure [51], introducing any kind of payment for waste disposal that motivates households to reduce their future bills for waste through recycling and sorting [52]. Unit and weight-based systems are generally found to be more effective than volume and frequency-based approach [53] and extended producer responsibility schemes facilitate implementation of polluter pays principle and cost internalisation and encourages consumers to embrace sorting and recycling [54].

Similar conclusions can be drawn about activity type in activity cluster 7.3 (Increase the number of households / houses connected to the centralised sewage system in certain agglomerations) where only type (B) activities can be identified currently.

\section{Discussion}

The 255 activities in the NECP2030 are distributed among 12 thematic activity groups and a set of horizontal activities. In three activity groups - RV 8, RV 9 and RV 10 - activities cannot be identified as having significant impact on energy user or having impact on energy user at all. Regardless of that, the activities can and have been identified according to the HCS approach (belonging to category A, B or C). Activities in all other activity groups and that have been identified as belonging to one or more categories/types are considered as having impact on energy user.

Certain conclusions can be drawn from the analysis of NECP2030 activity types according to the methodology set out in Section 2 (Methodology) on how the activities by type correlate with SEIA analysis about environmental impact of those same activities:

1. Type A (hugs) and type B (carrots) activities dominate in NEKP2030;

2. The number and proportion of type $\mathrm{C}$ or compulsory activities is significantly smaller than that of type A and B activities;

3. Type A and type B activities dominate in several activity groups (RV 3, RV 4, RV 6, RV 7, RV 9, RV 12), which causes doubt if this type of activities will be enough to achieve the required changes and the goals set for each respective activity group;

4. In general, the activities included in NECP2030 can be regarded as sufficient to achieve the goals of activity groups if implemented

\section{Conclusions}

After analysing information about each activity group and activity cluster including horizontal activities, following conclusions can be drawn about the type of activities in activity groups and activity clusters (RV): 
a) Activity clusters RV 3, RV 4, RV 5 and RV 7 encompass activities and policy instruments that may require additional attention as activities have been identified as potentially inadequate to achieve the desired goals.

b) RV 3 - Facilitating use of non-emission technologies in electricity production: According to SEIA activity clusters RV 3.1 and RV 3.3 have negative impact on environment. These two activity clusters are related to the development of wind energy and are the only two clusters and activities identified as having negative impact among all the NECP2030 activities. Activity cluster 3.6 plans to facilitate RES electricity trading through type (A) and type (B) activities although type (C) or mandatory activities might prove to be more effective.

c) RV 4 - Facilitating economically justified own energy production, consumption and renewable energy communities: Activities in activity clusters that according to SEIA have positive impact on environment, 5 activities have been identified as type (A) activities while having no type (B) or (C) activities. Activity cluster RV 4.3 has both type (A) and type (B) activities. Activity cluster 4.5 (energy efficiency in public sector) has two type (A) activities, however, literature suggests that imposing obligations can improve effectiveness of processes leading to the goal. Other activity clusters of this activity group can be considered as adequate.

d) RV 5 - Improving energy efficiency and use of alternative fuels and renewable energy technologies in transport: Activities in cluster 5.8 are aimed at facilitating use of railway as means modern and environmentally friendly public transportation. According to SEIA this activity cluster has positive impact on environment. From the point of view impact on energy user activities of the cluster are type (A) and type (B) activities. Analysis of factors facilitating change of behaviour of energy users suggests that to achieve the desired goal (facilitate use of public transport) type (C) (sticks) activities might be needed at least until energy users have adapted their behaviour to the new conditions - they are using public transport instead of private transport making the overall use of energy more efficient.

e) RV 7 - Improving efficiency of waste and wastewater management and reducing GHG emissions: According to SEIA activities in two activity clusters have positive impact on environment although no type (C) activity has been identified to achieve the goals of the cluster. Activity cluster 7.1 has several only type (B) activities that, according to NECP2030, will allow to successfully reach the goal. Literature suggests that type (C) activities might be required to implement a successful behavioural change of waste management practice. Similar conclusions can be drawn about activity type in activity cluster 7.3 where only type (B) activities have been included.

f) In case of activities in activity groups Horizontal activities, RV 1, RV 2, RV 6, RV 11 and RV 12 it can be considered that the type of activity corresponds the desired goals and use of type (C) (sticks) activities not required to a larger extent than currently or at all to achieve the desired goals.

g) Activities in Activity groups RV 8, RV 9 and 10 can only remotely be assessed, if at all, from the point of view of impact on energy user, as such impact can be indirect through increased or reduced use of fuel for agricultural machinery.

\section{ACKNOWLEDGEMENT}

This research is funded by the Ministry of Economics of the Republic of Latvia, project "Energy and climate modelling towards net zero emissions", project No. VPP-EM-2018/NEKP_0001. 


\section{REFERENCES}

[1] European Commission, The European Green Deal, (2019). [Online]. [Accessed 12.05.2020]. https://ec.europa.eu/info/sites/info/files/european-green-deal-communication_en.pdf.

[2] European Commission, Proposal for a REGULATION OF THE EUROPEAN PARLIAMENT AND OF THE COUNCIL establishing the framework for achieving climate neutrality and amending Regulation (EU) 2018/1999 (European Climate Law), 2020. [Online]. [Accessed 12.05.2020]. Available: https://www.consilium.europa.eu/media/39914/a-new-strategic-agenda-2019-2024-en.pdf.

[3] Boulding K. E. Three Faces of Power. CA: Sage, Newbury Park, 1990.

[4] Katre A., Tozzi A. Using hugs, carrots and sticks: How agents exercise power in the transition to community-owned energy systems in remote India. Energy Research and Social Science 2019:54:129-139. https://doi.org/10.1016/j.erss.2019.04.008

[5] Marmefelt T. Human knowledge, rules, and the spontaneous evolution of society in the social thought of Darwin, Hayek, and Boulding. Journal of Economic Behaviour \& Organization 2009:71:62-74. https://doi.org/10.1016/j.jebo.2009.02.013

[6] Kesting S. Boulding's welfare approach of communicative deliberation. Ecological Economics 2010:69:973-977. https://doi.org/10.1016/j.ecolecon.2009.12.010

[7] Beilock R. The impact of caring on exchange choices and efficiencies: a modification of Boulding's three social organizers. The Journal of Socio-Economics 2000:29(3):263-279. https://doi.org/10.1016/S1053-5357(00)00072-X

[8] Mahmoodi J., Prasanna A., Hille S., Patel M. K., Brosch T. Combining "carrot and stick" to incentivize sustainability in households. Energy Policy 2018:123:31-40. https://doi.org/10.1016/j.enpol.2018.08.037

[9] Rintamäki H., Rikkonen P., Tapio P. Carrot or stick: Impacts of alternative climate and energy policy scenarios on agriculture. Futures 2016:83:64-74. https://doi.org/10.1016/j.futures.2016.03.004

[10] Van Den Bergh J. C. J. M., Ferrer-I-Carbonell A., Munda G. Alternative models of individual behaviour and implications for environmental policy. Ecological Economics 2000:32(1):43-61. https://doi.org/10.1016/S0921$\underline{8009(99) 00088-9}$.

[11] Gardner G., Stern P. Environmental problems and human behaviour. Pearson Learning Solutions, 2002.

[12] Ophuls W. Levithian or Oblivion? in: Towar. a Steady State Econ., 1973.

[13] Abreu I. M., Oliveira R., Lopes J. Attitudes and Practices of Homeowners in the Decision-making Process for Building Energy Renovation. Procedia Engineering 2017:172:52-59. https://doi.org/10.1016/j.proeng.2017.02.016

[14] Rosenow J., Kern F., Rogge K. The need for comprehensive and well targeted instrument mixes to stimulate energy transitions: The case of energy efficiency policy. Energy Resource \& Social Science 2017:33:95-104. https://doi.org/10.1016/j.erss.2017.09.013

[15] Latvian National energy and climate plan. Enviroprojekts SIA, Latvijas Nacionālais enerǵêtikas un klimata plāns 2021. - 2030. gadam, Stratẹgiskais ietekmes uz vidi novērtējums, Vides pārskats, 2019. https://em.gov.lv/files/attachments/LNEKP_SIVN_12.2019.doc. (In Latvian).

[16] Mac Domhnaill C., Ryan L. Towards renewable electricity in Europe: Revisiting the determinants of renewable electricity in the European Union. Renewable Energy 2020:154:955-965. https://doi.org/10.1016/j.renene.2020.03.084

[17] Del Río P., Cerdá E. The missing link: The influence of instruments and design features on the interactions between climate and renewable electricity policies. Energy Research \& Social Science 2017:33:49-58. https://doi.org/10.1016/j.erss.2017.09.010

[18] Bao X., Zhao W., Wang X., Tan Z. Impact of policy mix concerning renewable portfolio standards and emissions trading on electricity market. Renewable Energy 2019:135:761-774. https://doi.org/10.1016/j.renene.2018.12.005

[19] Wang G., Zhang Q., Li Y., Mclellan B. C., Pan X. Corrective regulations on renewable energy certificates trading: Pursuing an equity-efficiency trade-off. Energy Economics 2019:80:970-982. https://doi.org/10.1016/j.eneco.2019.03.008

[20] Bento A. M., Garg T., Kaffine D. Emissions reductions or green booms? General equilibrium effects of a renewable portfolio standard. Journal of Environmental Economics and Management 2018:90:78-100. https://doi.org/10.1016/j.jeem.2018.05.006

[21] Bolkesjø T. F., Eltvig P. T., Nygaard E. An Econometric Analysis of Support Scheme Effects on Renewable Energy Investments in Europe. Energy Procedia 2014:58:2-8. https://doi.org/10.1016/j.egypro.2014.10.401

[22] Choi G., Huh S. Y., Heo E., Lee C. Y. Prices versus quantities: Comparing economic efficiency of feed-in tariff and renewable portfolio standard in promoting renewable electricity generation. Energy Policy 2018:113:239-248. https://doi.org/10.1016/j.enpol.2017.11.008

[23] Herbes C., Rilling B., MacDonald S., Boutin N., Bigerna S. Are voluntary markets effective in replacing state-led support for the expansion of renewables? - A comparative analysis of voluntary green electricity markets in the UK, Germany, France and Italy. Energy Policy 2020:141:111473. https://doi.org/10.1016/j.enpol.2020.111473 
[24] Barbose G., Bird L., Heeter J., Flores-Espino F., Wiser R. Costs and benefits of renewables portfolio standards in the United States. Renewable and Sustainable Energy Reviews 2015:52:523-533. https://doi.org/10.1016/j.rser.2015.07.175

[25] Chapman A. J., McLellan B., Tezuka T. Residential solar PV policy: An analysis of impacts, successes and failures in the Australian case. Renewable Energy 2016:86:1265-1279. https://doi.org/10.1016/j.renene.2015.09.061

[26] Polzin F., Migendt M., Täube F. A., von Flotow P. Public policy influence on renewable energy investments-A panel data study across OECD countries. Energy Policy 2015:80:2015. https://doi.org/10.1016/j.enpol.2015.01.026

[27] Aune F. R., Dalen H. M., Hagem C. Implementing the EU renewable target through green certificate markets. Energy Economics 2012:34(4):992-1000. https://doi.org/10.1016/j.eneco.2011.07.006.

[28] Bistline J., Santen N., Young D. The economic geography of variable renewable energy and impacts of trade formulations for renewable mandates. Renewable and Sustainable Energy Reviews 2019:106:79-96. https://doi.org/10.1016/j.rser.2019.02.026.

[29] Amundsen E. S., Bye T. Simultaneous use of black, green, and white certificate systems. The Energy Journal 2018:39. https://doi.org/10.5547/01956574.39.4.eamu.

[30] Xie M., Li C., Wang Y., Wang J. Comprehensive utilization of renewable energy for new civil buildings in Shanghai. Energy Procedia 2018:152:336-341. https://doi.org/10.1016/j.egypro.2018.09.144

[31] Marino C., Nucara A., Pietrafesa M., Pudano A. An energy self-sufficient public building using integrated renewable sources and hydrogen storage. Energy 2013:57:95-105. https://doi.org/10.1016/j.energy.2013.01.053

[32] Galatioto A., Ricciu R., Salem T., Kinab E. Energy and economic analysis on retrofit actions for Italian public historic buildings. Energy 2019:176:58-66. https://doi.org/10.1016/j.energy.2019.03.167

[33] Cabeza L. F., de Gracia A., Pisello A. L. Integration of renewable technologies in historical and heritage buildings: A review. Energy and Buildings 2018:177:96-111. https://doi.org/10.1016/j.enbuild.2018.07.058

[34] Aivars A., Zandeckis A., Timma L., Blumberga D., Rochas C. Possibilities for Utilization of Solar Thermal Energy in Multi-Family Buildings in Latvia. Environmental and Climate Technologies 2011:6(1):138-146. https://doi.org/10.2478/v10145-011-0020-4

[35] Jimenez-Bescos C., Oregi X. Implementing User Behaviour on Dynamic Building Simulations for Energy Consumption. Environmental and Climate Technologies 2019:23(3):308-318. https://doi.org/10.2478/rtuect-20190097

[36] Miezis M., Zvaigznitis K., Stancioff N., Soeftestad L. Climate change and buildings energy efficiency - The key role of residents. Environmental and Climate Technologies 2016:17(1):30-43. https://doi.org/10.1515/rtuect-2016-0004

[37] Alanne K., Liimatainen H. Design implications of the electrification of passenger vehicle stock on renewable energy integration in Finnish apartment buildings. Sustainable Cities and Society 2019:47:101507. https://doi.org/10.1016/j.scs.2019.101507.

[38] Huang J., Fan J., Furbo S., Li L. Solar water heating systems applied to highrise buildings-lessons from experiences in China. Energies 2019:12(16):3078. https://doi.org/10.3390/en12163078

[39] Fiaschi D., Bandinelli R., Conti S. A case study for energy issues of public buildings and utilities in a small municipality: Investigation of possible improvements and integration with renewables. Applied Energy 2012:97:101114. https://doi.org/10.1016/j.apenergy.2012.03.008

[40] Sussman R., Tan L. Q., Kormos C. E. Behavioral interventions for sustainable transportation: an overview of programs and guide for practitioners, in: Transport and Energy Research, Elsevier, 2020:315-371. https://doi.org/10.1016/b978-0-12-815965-1.00014-4

[41] Bamberg S. Is a stage model a useful approach to explain car drivers' willingness to use public transportation? Journal of Applied Social Psychology 2007:37:1757-1783. https://doi.org/10.1111/j.1559-1816.2007.00236.x

[42] Bamberg S., Schmidt P. Choice of Travel Mode in the Theory of Planned Behavior: The Roles of Past Behavior, Habit, and Reasoned Action. Basic and Applied Social Psychology 2010:25(3):175-187. https://doi.org/10.1207/S15324834BASP2503 01

[43] Wang S., Wang J., Yang F. From willingness to action: Do push-pull-mooring factors matter for shifting to green transportation? Transportation Research Part D: Transport and Environment 2020:79:102242. https://doi.org/10.1016/j.trd.2020.102242

[44] Carrus G., Passafaro P., Bonnes M. Emotions, habits and rational choices in ecological behaviours: The case of recycling and use of public transportation. Journal of Environmental Psychology 2008:28:51-62. https://doi.org/10.1016/j.jenvp.2007.09.003

[45] Ercan T., Onat N. C., Tatari O., Mathias J. D. Public transportation adoption requires a paradigm shift in urban development structure. Journal of Cleaner Production 2017:142(4):1789-1799. https://doi.org/10.1016/j.jclepro.2016.11.109

[46] Nyborg K. The Impact of Public Policy on Social and Moral Norms: Some Examples. J. Consum. Policy. 2003:26:259-277. https://doi.org/10.1023/a:1025622223207

[47] Andersson C., Stage J. Direct and indirect effects of waste management policies on household waste behaviour: The case of Sweden. Waste Management 2018:76:19-27. https://doi.org/10.1016/j.wasman.2018.03.038 
[48] Bel G. Effects of unit-based pricing on household waste collection demand: A meta-regression analysis. Resource and Energy Economics 2016:44:169-182. https://doi.org/10.1016/j.reseneeco.2016.03.003

[49] Arvidsson A., Stage J. Technology-neutral green procurement in practice-an example from Swedish waste management. Waste Management \& Research: the Journal of a Sustainable Circular Economy 2012:30:519-523. https://doi.org/10.1177/0734242X12437566

[50] Abbott A., Nandeibam S., O'Shea L. Explaining the variation in household recycling rates across the UK. Ecological Economics 2011:70:2214-2223. https://doi.org/10.1016/j.ecolecon.2011.06.028

[51] Hage O., Sandberg K., Söderholm P., Berglund C. The regional heterogeneity of household recycling: a spatial-econometric analysis of Swedish plastic packing waste. Letters in Spatial and Resource Science 2018:11:245267. https://doi.org/10.1007/s12076-017-0200-3

[52] Czajkowski M., Hanley N., Nyborg K. Social Norms, Morals and Self-interest as Determinants of Pro-environment Behaviours: The Case of Household Recycling. Environmental and Resource Economics 2017:66:647-670. https://doi.org/10.1007/s10640-015-9964-3

[53] Dijkgraaf E. Cost savings in unit-based pricing of household waste: the case of the Netherlands. 2004:26(4):353371. https://doi.org/10.1016/i.reseneeco.2004.01.001

[54] Leclerc S. H., Badami M. G. Extended producer responsibility for E-waste management: Policy drivers and challenges. Journal of Cleaner Production 2020:251:119657. https://doi.org/10.1016/j.jclepro.2019.119657 